\title{
Induced Civic Pride and Integration
}

\author{
BERND SÜSSMUTH \\ MALTE HEYNE \\ WOLFGANG MAENNIG
}
CESIFO WORKING PAPER No. 2582
CAtegory 2: Public ChOice
MARCH 2009
An electronic version of the paper may be downloaded
- from the SSRN website: $\quad$ www.SSRN.com
- from the RePEc website: $\quad$ www.RePEc.org
- from the CESifo website: www.CESifo-group.org/wp




\title{
Induced Civic Pride and Integration
}

\begin{abstract}
This paper investigates whether a nation's contingent value of hosting a mega-event depends on past experience with implied public goods benefits for its residents. Applying data from an ex-ante and ex-post query based on contingent valuation methods, we use the FIFA World Cup 2006 as a natural experiment. The significant ex-post increase in valuation is shown to be due to adventitious citizens requiring an involving experience, rather than to an updating of a prior assessment. The World Cup finals were the first mega-event hosted by reunified Germany. We use this landmark event in German contemporary history to investigate how the integration of the two parts of Germany progressed after 18 years of reunification. We still find a profound difference in clear-sighted civic awareness of East and West German individuals. However, civic pride induced by collective experience can considerably accelerate the convergence of East Germans' preferences towards those of West Germans, which Alesina and Fuchs-Schündeln (2007) recently calculated to take 20 to 40 years or one and a half generation.
\end{abstract}

JEL Code: H49, H59, L83.

Keywords: experience goods, contingent valuation, civic awareness, German reunification.

Bernd Süssmuth

Department of Business and Economics

TUM Munich University of Technology

Arcisstrasse 21

Germany - 80333 Munich

suessmuth@wi.tum.de

\author{
Malte Heyne \\ Hamburg Chamber of Commerce \\ Germany - Hamburg \\ malte.heyne@hk24.de
}

\author{
Wolfgang Maennig \\ University of Hamburg \\ Department of Economics \\ Von-Melle-Park 5 \\ Germany - 20146 Hamburg \\ w.maennig@econ.uni-hamburg.de
}

We would like to thank Kelly Bedard, Elizabeth A. Dhuey, Javier Birchenall, Alexander Raulfs, Peter Kuhn, Vic Brajer, Gert G. Wagner, and seminar participants at various places for helpful comments and suggestions. We also greatly benefited from comments by Beata Javorcik and an anonymous referee. Bernd Süssmuth acknowledges the hospitality of the economics department at the University of California, Santa Barbara, where parts of this paper were finalized. 


\section{Introduction}

Mass-televised mega-events like the Olympics, the FIFA ${ }^{1}$ World Cup (FWC) finals, or the Miss Universe Beauty Pageant attract the attention of a myriad of people, implying a variety of potential economic externalities. Baade and Dye (1988), Baim (1994), Kang and Perdue (1994), Teigland (1999), Coates and Humphreys (1999, 2003), Baade and Matheson (2000, 2004), Szymanski (2002), Hotchkiss et al. (2003), and Hagn and Maennig $(2008,2009)$ test for positive economic effects of such events and the required facilities. Coates and Humphreys (2003) give a comprehensive survey of both economic impact studies assessing the pecuniary benefits and studies devoted to the non-pecuniary or "consumption" benefits to residents of the host countries of mega-sporting events.

Recently, a related strand of literature emanated from cultural and environmental economics. It is concerned with the quantification of intangible economic ramifications of subsidized (public) goods such as the hosting of Major League teams, the Eurovision Song Contest, the Olympics, the UEFA $^{2}$ European Championship finals, and the construction of stadiums in a city (Johnson and Whitehead 2000, Johnson et al. 2001, Fleischer and Felsenstein 2002, eftec 2005, Barros 2006). This young body of literature adheres to the Contingent Valuation Method (CVM). It assesses positive externalities that are not directly internalised by the market by quantifying the corresponding willingnessto-pay (WTP) of the concerned taxpayers (Arrow et al. 1993).

To our knowledge the notion of experience goods - those for which consumers cannot assess use value in advance but only upon consumption or from past experience (Nelson 1970, van der Ploeg 2002) - has not yet been empirically investigated in relation

\footnotetext{
${ }^{1}$ Fédération Internationale de Futbol Association (International Federation of Association Football)
} 
to CVM or sports, although von Ungern-Sternberg and von Weizsäcker $(1985$, p. 534)

suggested two decades ago that this be done.

Apart from the aim of filling this gap in the literature, we find the 2006 FWC championship as our object of investigation particularly challenging: It is the first megaevent hosted by reunified Germany. This makes it an opportunity to exploit the division of Germany after the Second World War and the reunification of East and West Germany in 1990 as a source of exogenous variation (Alesina and Fuchs-Schündeln 2007, Redding and Sturm 2008) ${ }^{3}$. We use the FWC as a landmark event in German contemporary history to investigate how the integration of the two parts of Germany progressed after more than one and a half decade of reunification. Based on our measure of a-priori assessing the intangible net benefit of government services (i.e., of hosting the 2006 FWC), we still find a profound difference. In this sense, the findings from our ex-ante query are confirmatory evidence for the results reported in the seminal study by Alesina and FuchsSchündeln (2007). Similarly, these authors assess attitudes towards and preferences for pro-state provision of services that could as well be provided by private forces. In contrast to our study, households of the panel (German Socioeconomic Panel) underlying their estimates were not asked for a concrete WTP of these services but for answers on a 1 to 5 scale of preferences for private provision (Alesina and Fuchs-Schündeln, 2007, p. 1511-1512). However, the results from our ex-post study raise some skepticism on the duration of convergence of East Germans' preferences towards those of West Germans calculated by Alesina and Fuchs-Schündeln. Accordingly, preferences need one to two

\footnotetext{
${ }^{2}$ Union of European Football Associations

${ }^{3}$ While Redding and Sturm (2008) rely on the division of Germany as central source of exogenous variation, we follow Alesina and Fuchs-Schündeln (2007) in that our focus is on German reunification.
} 
generations to converge. This insight - based on comparing queries from the year 1997 with corresponding ones from 2002 - abstracts from the possibility that singular events like the hosting of the FIFA FWC can induce a sort of corporate citizenship that may considerably accelerate this convergence. In the present study, predominantly East Germans change their WTP from a zero to a positive value after experiencing the event. We interpret this "jump start" change of preferences as such a positive shock on the linearly extrapolated trajectory of convergence by Alesina and Fuchs-Schündeln.

In two recent papers the level of educational attainment has not only be found to be a causal factor for civic participation and engagement but also for civic awareness and knowledge (Dee 2004 and Milligan et al. 2004). We, therefore, also address the question whether and by how much education compensates for the lack of and impacts on the ability in clear-sighted civic awareness by West German and, in particular, also by East German individuals.

Our study contributes to the literature in the following points. First, it offers an independent ${ }^{4}$ and representative CVM-based quantification of the German population's WTP for hosting the 2006 FWC finals. Secondly, it unravels the nation's assessments of intangibles before and after the event. ${ }^{5}$ Central determinants such as age and educational background are identified using censored regression models. Finally, we quantify the difference in anticipatory civic awareness of East and West Germans, and investigate to

\footnotetext{
${ }^{4}$ This does, for example, not apply to eftec (2005). For a critique of commissioned and frequently upward biased economic impact studies see Coates and Humphreys (2003, p. 339).

${ }^{5}$ While Baade and Matheson (2004) is an example for a retrospective study, the eftec (2005) CVM analysis of the London 2012 Olympics and the one by Barros (2006) on "the Euro 2004" in Portugal clearly are of the ex-ante type.
} 
what extent schooling compensates for a lack of experience with publicly provided intangibles.

\section{Data and Empirical Approach}

Three months prior to and three months after the 2006 FWC finals in Germany, that is, in March and October, we conducted two online surveys. Our sample consists of 500 individuals. ${ }^{6}$ They are drawn from the ComCult Online Panel which is stratified by TNS Emnid, one of Germany's leading institutes in social science survey research. It is a representative sample for the German population aged 14 to 70 , for which participants were recruited both online and offline. Respondents in the survey prior to the event were the same that participated in the follow up after the event.

There are several papers that document what has become known as "warm glow"-effect in the context of CVM (see, e.g., Andreoni 1989, Kahnemann and Knetsch 1992, Nunes and Schokkaert 2003). Accordingly, survey participants potentially gain some sort of moral satisfaction through the mere act of giving per se. This effect relates to concepts such as peer-group pressure, feelings of guilt, and sympathy. It superimposes a "cold" WTP, in particular, in face-to-face interviews. The fact that the bias induced by a "warm glow" is pronounced for personal interviews is documented by Schkade and Payne (1994) who analyze verbal protocols of CVM-based studies. These authors find that some

\footnotetext{
${ }^{6}$ Sixteen respondents of the ex-ante survey $(3.2 \%)$ did not participate in the ex-post survey. We treat them as sticking to their ex-ante valuation. Notably, our results do not change qualitatively if we drop these individuals from the sample.

${ }^{8} \mathrm{We}$ do so in several regards. For example, we intentionally want respondents to recall their answers given in the pre-survey, when asking for their ex-post evaluation. This clearly violates the idea of assessing the test-retest reliability of contingent values. A test-retest reliability in our case can only be achieved for the post-survey's contingent value. However, apart from the delicate question of the appropriate time between first and second administration of the CV question, such an assessment is beyond the scope of the present paper.
} 
respondents vocalize a parallel with charitable contributions when answering the WTP survey in front of an interviewer. We can interpret this finding as lending support to the hypothesis that the "warm glow" is a relevant bias in personal rather than in online interviews as in the one of the present study.

Before going into detail of our survey design, we want to be clear about two central points of our study. First, although we rely on a contingent valuation (CV) framework that is used to measure a nonuse value, the intangible we seek to quantify consists of benefits derived from experiencing the hosting of a mega-event in a host country. Usually, nonuse values by definition are the benefits derived from not experiencing a certain good or service. However, in our case the frequency of experiencing the use as well as the nonuse value of such an event is extremely low. On average, the FWC hosted in one's home country is experienced by residents of a developed country less than once in a lifetime. The value we aim to capture is rather related to public goods benefits like non-smoking areas at train stations or airports, for which you need the experience of polluted air as a prerequisite to value these areas as an achievement. In the case of the FWC, it is primarily the civic pride and "feel good factor" that capture the nonuse values that the hosting of a mega-event provides. In essence, you experience the good through TV or public viewing, news paper articles, and the civic pride in the country and not by going to the event itself. Therefore, these benefits are not captured in ticket prices. Secondly, our strategy of a pre- and post-survey based on CV techniques can be interpreted as intentionally violating the requirement of what is called 'temporal reliability' in the literature on CVM-based estimates of Hicksian surplus measures (Reiling et al. 1990). ${ }^{8}$ Accordingly, a low variability of estimated contingent 
values of a specific population over time is "a necessary condition for accurate value estimates." This holds for a population in which experience of the nonuse value is either zero (cf. our argumentation above) or can be made by every individual in the population with a positive probability. However, it does not apply here: A significant part of the German population never experienced the hosting of a mega-event in Germany, either because they were too young or because of their fate to have been born and grown up in the German Democratic Republic (GDR) that never hosted such an event. Therefore, we ultimately analyse two different populations: In the pre-survey, one for which at least 20 percent of the population have zero experience and in the post-survey, a population for which everyone experienced the public goods benefits. The vast majority of people currently living as residents in East Germany and being born before the 1990s actually experienced one of the most rigid regimes of the former Communist block.

From a peak population of 19.1 million people living in 1947 in the Soviet zone that officially became the GDR in 1949 , about three million people emigrated into the Federal Republic of Germany (FRG) before the Berlin Wall was built in 1961. By 1988, only about 600,000 people emigrated from East to West. This 3.6 million East-West migrants contrast with just around 30,000 people per year emigrating from East to West in the 1950s, and almost no West-East migration after $1961 .{ }^{9}$ Based on data from two waves of the German Socioeconomic Panel, Alesina and Fuchs-Schündeln (2007) find only 0.6 percent of West Germans living in the East and seven percent of East Germans who migrated to the West. This makes us confident to capture individuals of reasonable

\footnotetext{
${ }^{9}$ For sources of migration figures see Alesina and Fuchs-Schündeln (2007, p. 1510). Another concise historical background of the division of Germany, highlighting the implied cut through regions of prewar Germany that had been integrated through several centuries can be found in Redding and Sturm (2008, p.
} 
age who are not just "East residents" but whose fate it also was to have been born and grown up in the GDR.

In the quarter prior to the start of the tournament the subjects were confronted with a series of questions concerning their general attitude towards football, mega-events, and the FWC. It was followed by a counterfactual scenario: "Suppose that shortly before the beginning of the cup finals, severe doubts on whether Germany can really stage the 2006 FWC finals are raised. They concern such issues as weak status of stadium construction and potential terrorist attacks. Therefore, the FIFA is tending toward relocating the cup finals to Switzerland, where an ideal infrastructure is ready to stage the matches thanks to early and thorough preparation of the Swiss co-hosting of the 2008 European Cup finals. There is still a chance that the tournament will take place in Germany, but only if a series of costly safety measures are adopted. However, these previously unplanned measures can only be financed with immediate voluntary contributions from the population. Would you personally be willing to contribute some of your own money to ensure the finals can be hosted in your home country?"

In a series of pre-tests, the questionnaire and, in particular, also the above scenario were carefully tested. The pre-tests provided relevant information with regard to participants' understanding and potential caveats of the scenario. In a first version, we considered, for example, France (the host of the FWC 1998) as backup-host instead of Switzerland in our counterfactual scenario. However, the fact of a historically developed rivalry between Germany and France obviously biased the WTP of respondents in our

1770-1771). It also gives an account of the sparse migration flows between East and West Germany after the construction of the Berlin Wall in 1961. 
pre-tests. ${ }^{10}$ Its traditional status of neutrality and its rather minute territory, therefore, made Switzerland the ideal and realistic candidate for our CV-scenario. According to our pre-test runs, respondents assessed the final scenario as realistic. ${ }^{11}$ This is also reflected by a fairly low termination rate of interviews in the pre-event survey of less than 1.7 percent.

Rather than using a dichotomous choice framework, we rely on another closedended valuation question, that is, a valuation question in payment card format (Whitehead 2006). Ranges of possible WTP-values are obtained from the pre-tests. In accordance with the latter, the ultimate of six ranges is truncated at 70 Euros. Nevertheless, respondents were also given the possibility to express another (possibly higher) amount. As is standard in CV-studies, we used reminders of budget constraints to minimise hypothetical bias of respondents.

Besides bias associated with the hypothetical nature of $\mathrm{CV}$-questions, free riding behaviour is an obvious qualification. A respondent may not reveal her true WTP for an intangible such as the hosting of the FWC, expecting to benefit from others who are willing to pay for it. A number of strategic methods ("incentive compatible mechanisms") have been suggested in the literature that let respondents find it in their self-interest to reveal their true WTP. Here, we implicitly used one such mechanism: the provision point. The provision point mechanism is implied by a scenario that states that unless a minimum

\footnotetext{
${ }^{10}$ Detail is available on request from the authors.

${ }^{11}$ In the months prior to the FWC, several incidences made the cancellation of Germany's hosting of the event not a far-fetched scenario. These incidences include the spread of the bird flu and the publication of an independent assessment of world cup stadiums by Stiftung Warentest - a product testing foundation that compares to the Consumers Union ("test") in the U.S. and to the Consumers' Association ("Which?") in the U.K. - revealing several construction deficiencies. At the time, also a public discussion (that goes on to the present day) was triggered, asking whether the bringing down of a hijacked passenger plane by the German Federal Armed Forces is a safety measure in accordance with the Constitution.
} 
amount of money (i.e., the provision point) is raised, the good or service in question will not be available to anybody. It reduces the incentive to free ride as the respondent risks losing the benefit if a minimum amount of money is not raised. Although we did not include a specific minimum amount, a money-back guarantee, or a proportional rebate rule in case of excess contributions, a provision point is implied by formulations like "...can only be financed with immediate voluntary contributions from the population." Even though, it seems that the profession has not yet reached a consensus on the value added of provision points, ${ }^{12}$ they have the potential to reduce free riding and to increase the proportion of demand revealed in large group, single-shot environments (Rondeau et al. 1999, Poe et al. 2002).

A quarter of a year after the Cup, the same persons were asked a "groundhog day"-question: $:^{13}$ "About six months ago you were asked in a counterfactual scenario about your willingness-to-pay for your home country to host the football world cup finals. Now that you experienced it, imagine yourself back in March: Would you change your mind and/or adjust the amount you would be willing to pay?"14

The results of the questionnaire preceding the CV-part of the ex-ante survey can be summarised as follows: Almost 85 percent of the German population thought their

\footnotetext{
${ }^{12}$ For a rather optimistic appraisal of provision point mechanisms see Poe et al. (2002). In contrast, Champ et al. (2002) find no statistically significant difference in WTP assessments with and without provision point.

${ }^{13}$ Both the ex-ante and ex-post query did not allow respondents to refuse an answer, except for the rather delicate question on personal income and status of employment. We cut down on respondents clicking through the questionnaire by dropping participants that remained on the survey pages for less than a minimum time per page.

${ }^{14}$ The same caveats discussed in the preceding paragraphs apply to the ex-post survey as there are no actual costs implied, whatever respondents state to be their WTP. However, it seems reasonable that at least the free rider bias does not change from ex-ante to ex-post situation. It will, therefore, not obscure our assessment of an experience good nature. To preclude a possible change in the hypothetical bias is a more difficult task that is beyond the scope of the present study.
} 
home country's hosting of the FWC to produce an overall net benefit for Germany. Regardless of some critical discussion in the advent of the FWC year, the Germans attested the national Organising Committee a good job. More than 80 percent assessed the organisation of hosting the cup (three months prior to the event) as "rather positive." As expected, the overall interest of the German population in football is found to be fairly high: Less than 7 percent of respondents indicated to never speak with their acquaintances about football in any way.

\section{Findings and Estimates}

3.1 Contingent values and choice of model. Overall, we find that ex ante less than every fifth German has a positive WTP. However, after the event 42.6 percent of the population report a positive WTP. The corresponding increase is 129 percent. In sum, 26.6 percent of subjects changed their mind; 14.2 percent of these decreased their WTP, a vast majority of 85.5 percent increased it.

The average ex-ante WTP for the whole sample is 4.26 Euros per person, which gives a total mean WTP of 351.5 million Euros for a total population of 82.5 million Germans. ${ }^{15}$ The average ex-ante WTP for individuals with a strictly positive WTP is 22.90 Euros. The average ex-post WTP for the whole sample is 10.07 Euros per person, which gives a total mean WTP of 830.78 million Euros. The average ex-post WTP of test

\footnotetext{
${ }^{15}$ As mentioned above, respondents were given the possibility to name an amount outside the ranges given in payment card format. This opportunity has been taken by one respondent, who entered an amount of 100 Euros. Additionally, in the final part of the survey all participants were given the possibility to correct their chosen WTP stated in the CV-question. Again, this opportunity has been taken by just one person, who corrected the given WTP of 70 Euros into an amount of 100 Euros. Including these adjustments in the computation of the total mean WTP of the population changes the resulting value by less than 10 million Euros.
} 
persons with a WTP $>0$ is 23.62 Euros. The average change in WTP is positive and amounts to 6.00 Euros. For the total population it is a substantial 495 million Euros.

Notably, there is a relatively small change of 72 cents in average WTP for the sub-sample of subjects with a WTP $>0$. The substantial increase in overall WTP can be attributed to persons reporting a zero WTP ex ante and a positive ex-post WTP after experiencing the event. Who are these subjects?

Residents have an expected heterogeneous benefit from the national hosting (Table 1). They also face an individual shadow price of avoidable costs in case of relocation. This weighing-up against the reservation position depends on characteristics like age (AGE), educational level (EDU), gender (MALE), region (BERLIN, ${ }^{16}$ EAST), and employment status (WORK). If this propensity is correlated with the actual value (WTP), a selectivity problem arises. We use the two-step Heckit to test and account for it. The discrete choice decision is identified by AGE and BENEFIT; that is, these two regressors are excluded from the outcome equation (second step). BENEFIT is a dummy of whether a respondent sees an overall benefit for Germany or not. ${ }^{17}$ By this identification in the bivariate model we make a functional form assumption. Accordingly, we let AGE and BENEFIT make individuals more likely to report a WTP $>0$ but assume that changes in these two variables make them not to report higher values. In general, this

\footnotetext{
${ }^{16}$ We include a dummy variable taking on a value of one if a respondent is an inhabitant of the city of Berlin. Our prior for the estimate of this coefficient is a negative sign for several reasons. First, the city state Berlin is among the federal states of Germany with the highest public indebtedness and the lowest per capita income. The latter is just about half the average of the one of the other most populated German cities: Hamburg, Munich, Cologne, and Frankfurt. Therefore, Berlin taxpayers might be downward biased in their WTP due to seeing the provision of other public goods as more important and pressing. Second, in the advent of the cup, Berlin witnessed a public discussion on "no-go-areas." It was triggered by politicians and officials who planned ascribing (parts of) the eastern quarters of the city the status of "no-go-areas" for colored FWC visitors due to xenophobic attitudes of inhabitants and potential neo-Nazi appearance. These circumstances can possibly undermine a positive attitude of the inhabitants of Berlin towards the hosting of the event.
} 
type of assumption is inevitable for a straightforward procedure like the Heckit to check whether sample selectivity correction is adequate. The check is performed by a test of the estimated coefficient for the inverse Mills ratio $(\lambda)$ with which the Heckit model augments the regression in its second step (Cameron and Trivedi 2005, p. 550-555).

Selectivity is only relevant for explaining the final WTP (Table 1). It does not matter for the ex-ante WTP and the change in WTP. This suggests looking at the respective Tobit models that we censored left ( 0 for WTP1 and -70 for $\Delta \mathrm{WTP}$ ) and right (70) due to 70 Euros being the upper WTP-threshold in our survey. While the educational level has a sizable, positive, and statistically significant impact on WTP1, it impacts negatively on $\Delta \mathrm{WTP}$, though to a lesser extent. This allows the interpretation that it was primarily the less educated who changed their WTP after the tournament. In the vast majority of cases, they did so from a zero value to a WTP $>0$. However, this behaviour is even more pronounced for residents of eastern Germany. A change in WTP is also positively dependent on whether an individual has a job or not (WORK). In nearly all specifications, age is negatively related to WTP and change in WTP.

So far, we find two intriguing facts and evidence in favor of an experience goods character: First, the lion's share, i.e. 88 percent, of the ex-post increase in valuation of roughly 0.5 billion Euros can be attributed to adventitious contributors to the aggregate WTP (with zero ex-ante WTP) rather than to a basic updating of the individual ex-ante WTP. Second, because it is relatively difficult to assess the intangibles involved in staging a mega-sporting event, residents with a lower educational level require

\footnotetext{
${ }^{17}$ We asked a corresponding question preceding the CV-part of the survey; see the end of Section 2 above.
} 
experience for their valuation. The latter also holds for citizens from regions of the former GDR due to their lack of past experience.

3.2 Marginal effects: McDonald-Moffit decompositions. The standard censored regression (Tobit) model is given by

$$
\begin{aligned}
& y=\left\{\begin{array}{cc}
y_{i}^{*}=\beta^{\prime} X_{i}+\varepsilon_{i} & \text { for } y_{i}>0 \\
0 & \text { for } y_{i} \leq 0
\end{array},\right. \text { where } \\
& \mu=\beta^{\prime} X ; y_{i}^{*} \mid X_{i} \sim N\left(\beta^{\prime} X_{i}, \sigma^{2}\right) .
\end{aligned}
$$

The corresponding marginal effects are

$$
\begin{aligned}
& \frac{\partial E\left(y_{i} \mid X_{i}\right)}{\partial X_{i}}=\beta \Phi\left(\frac{\beta^{\prime} X}{\sigma}\right)\left[1+\frac{\beta^{\prime} X}{\sigma} \frac{\phi(\mu \mid \sigma)}{\Phi\left(\beta^{\prime} X \mid \sigma\right)}\right] \text { and } \\
& \frac{\partial E\left(y_{i}^{*} \mid X_{i}\right)}{\partial X_{i}}=\beta,
\end{aligned}
$$

In this set-up (1) to (4), $\Phi$ and $\phi$ denote the standard normal cumulative distribution function and probability density function, respectively. $\sigma$ is the standard deviation given from the conditional distribution of the latent variables $y_{i}^{*}$ in (2).

While the marginal effects (4) have no direct economic interpretation, the marginal effects (3) can be calculated as (i) marginal effects on the uncensored probability, (ii) conditional on being uncensored, and as (iii) unconditional expected values (McDonald and Moffit 1980). A sample interpretation of such a decomposition makes the point: As can be seen from the results reported for specification ix in Table 4, one year of additional schooling (i) increases the probability that an individual has a positive ex-ante WTP by one percent $(0.010)$; (ii) increases the WTP of an individual 
with positive ex-ante WTP by 35.1 Cents (0.351); (iii) increases the overall expected exante WTP by 31.5 Cents $(0.315)$.

If we consider educational credentials instead of years of education as regressor (variable EDU), the effect of education on WTP1 is even more pronounced; see estimates of specification vi in Table 4: One additional educational qualification increases the individual probability of having a positive WTP1 by 4.2 percent. It increases the WTP1 of an individual with WTP1 $>0$ by 1.43 Euros and the overall expected WTP1 by 1.19 Euros. In the literature on the returns to education, this amplification is referred to as "sheepskin effects" (Chevalier et al. 2004). However, if education merely reflects income - through (labour market) returns on education - in our estimates, we would expect a significant coefficient for INC in a specification which includes incomes but no educational variable (specification viii). In this case, we would also expect significant coefficient estimates for INC and SCHOOL if both variables are included (specification ix); cf. the argument in Chevalier et al. (2004, p. F509). Neither is the case here.

While age has a weakly significant and quantitatively negligible negative effect on WTP1 in specification viii, neither sex, employment status and region nor the number of years spent as an adult in the GDR have a significant impact on WTP prior to the cup.

For our specifications, explaining the individual change in WTP $(\Delta \mathrm{WTP})$ after experiencing the event as an inhabitant of the host country, the impact of schooling turns into a significant negative one: One year of additional schooling decreases the probability that an individual changes her WTP - compared to the pre-event situation - by one percent $^{18}$ (marginal effect on uncensored probability, specification vii, Table 5).

\footnotetext{
${ }^{18}$ Doubling this effect (in absolute size) roughly gives the corresponding sheepskin effect (specification vi).
} 
However, this only holds as long as the gender dummy (MALE) coefficient is estimated as insignificantly different from zero; else it is estimated as having a weakly insignificant impact on $\triangle \mathrm{WTP}$ (corresponding p-value equals 13 percent). In terms of size, gender and employment effects (MALE, WORK) stand out. Being employed (male) increases the probability of changing one's WTP after experiencing the cup by 10.1 (7.0) percent. It increases the magnitude of an adjustment by an individual with $\Delta \mathrm{WTP}>0$ by $4.09(2.95)$ Euros and the overall expected $\Delta$ WTP by 4.09 (2.96) Euros. Whether or not a person sees an overall benefit in Germany's hosting of the cup (BENEFIT) now only significantly influences the probability of changing one's attitude. It does not significantly alter the size (in terms of Euros) of a potential adjustment.

For our assessment of whether and to what extent revealed preferences of citizens for a domestic hosting of the mega-event depend on past experience, we look at the coefficient estimates for the years a person spent as an adult in the GDR (GDRYRS). ${ }^{19}$ Accordingly, one additional year (decade) a person spent as an adult in the system makes her more probable to change the ex-ante WTP by about 0.2 to 0.3 (2 to 3 ) percent. For example, a person who spent the maximum of 36 years of her lifetime in the communist system has basically no real-world experience with her home country hosting an international event. Consequently, other things equal, she is about 10 percent more likely to adjust her ex-ante WTP after experiencing the event (Table 5). This might be explained by the reasoning that ex ante "East Germans believe much more so than West Germans that social conditions determine individual fortunes" (Alesina and Fuch-Schündeln, p.

\footnotetext{
${ }^{19}$ This positive (negative) interaction of age and inexperience (implicit WTP for benefits from public goods and services) of East Germans is also documented in the findings of Alesina and Fuchs-Schündeln (2007, p. 1514-1515).
} 
1508). Consequently, without prior knowledge or experience of the intangibles generated by a domestic hosting, they see money better spent for tangible social goods and services than for staging a mega-event like the FWC.

Another finding consistent with the results obtained by Alesina and FuchsSchündeln $(2007$, p. 1513-1514, 1518) is the role of higher levels of education which to some extent reflect expected future income: Ceteris paribus, one additional year of schooling compensates the effect of 4.5 years spent as an adult in the GDR. An additional educational credential roughly compensates the effect of one decade spent after adolescence behind the "Iron Curtain."

\section{Conclusion}

This paper is the first to investigate whether a nation's contingent value of hosting a mega-event depends on past experience with implied public goods benefits for its residents. We have shown that by inducing civic pride through collective experience single events like the hosting of the FWC in 2006 have the potential to considerably accelerate the convergence of East Germans' preferences towards those of West Germans. According to our findings, such events that may be also paralleled by directed education policies can significantly impact as positive shock on the trajectory and duration of convergence estimated by Alesina and Fuchs-Schündeln (2007). In this sense our findings on the endogeneity of preferences to political regimes is by far less pessimistic. Although, we confirm the effects of Communism on preferences to be existent and to some extent also "large," we do not find them to be "long-lasting," and in particular, suggest them not to be politically unchangeable. 
Our empirical strategy to investigate the potential of collective experience to instill public citizenship and to speed up integration could be applied to a series of historical and future events. One such future task is the analysis of the upcoming 2010 FWC hosted by South Africa and its effects on a common feeling of civic pride. 


\section{References}

Alesina, A. and N. Fuchs-Schündeln. 2007. Good-Bye Lenin (or Not?): The Effect of Communism on People's Preferences. American Economic Review 97, 15071528.

Andreoni, J. 1989. Giving with Impure Altruism: Applications to Charity and Ricardian Equivalence. Journal of Political Economy 97, 1447-1458.

Arrow, K., Solow, R., Portney, P., Leamer, E., Radner, R., and H. Schuman. 1993. Report of the NOAA Panel on Contingent Valuation. Federal Register 58, 46014614.

Baade, R. A. and R. F. Dye. 1988. An Analysis of the Economic Rationale for Public Subsidization of Sports Stadiums. Annals of Regional Science 22, 37-47.

Baade, R. A. and V. A. Matheson. 2000. An Assessment of the Economic Impact of the American Football Championship, the Super Bowl, on Host Communities. Reflets et Perspectives 39, 35-46.

----. 2004. The Quest for the Cup: Assessing the Economic Impact of the World Cup. Regional Studies 38, 343-354.

Baim, D. V. 1994. The Sports Stadium as a Municipal Investment. Westport (Conn.): Greenwood Press.

Barros, C. P. 2006. Evaluating Sport Events at European Level: the Euro 2004. International Journal of Sport Management and Marketing 1, 400-410.

Cameron, A. C. and P. K. Trivedi 2005. Microeconometrics: Methods and Applications. New York: Cambridge University Press.

Champ, P. A., Flores, N. E., Brown, T. C., and J. Chivers. 2002. Contingent Valuation and Incentives. Land Economics 78, 591-604.

Chevalier, A., Harmon, C., Walker, I., and Y. Zhu. 2004. Does Education Raise Productivity, or Just Reflect It?. Economic Journal 114, F499-F517.

Coates, D. and B. R. Humphreys. 1999. The Growth Effects of Sport Franchises, Stadia, and Arenas. Journal of Policy Analysis and Management 18, 601-624. 
-_--. 2003. Professional Sports Facilities, Franchises and Urban Economic Development. Public Finance and Management 3, 335-357.

Dee, T. S. 2004. Are there Civic Returns to Education?. Journal of Public Economics 88, 1697-1720.

eftec. 2005. Olympic Games Impact Study - Stated Preferences Analysis. Final Report for the Department of Culture, Media and Sport, London.

Fleischer, A. and D. Felsenstein. 2002. Cost-Benefit Analysis Using Economic Surpluses: A Case Study of a Televised Event. Journal of Cultural Economics 26, 139-156.

Hagn, F. and W. Maennig. 2008. Employment Effects of the Fotbal World Cup 1974 in Germany. Labour Economics 15, 1062-1075.

----. 2009. Labour Market Effects of the Football World Cup 2006 in Germany; forthcoming in Applied Economics.

Hotchkiss, J., Moore, R. E., and S. M. Zobey. 2003. Impact of the 1996 Summer Olympic Games on Employment and Wages in Georgia. Southern Economic Journal 69, 691-704.

Johnson, B. K. and J. C. Whitehead. 2000. Value of Public Goods From Sports Stadiums: The CVM Approach. Contemporary Economic Policy 18, 48-58.

Johnson, B. K., Groothuis, P. A., and J. C. Whitehead. 2001. The Value of Public Goods Generated by a Major League Sports Team: The CVM Approach. Journal of Sports Economics 2, 6-21.

Kahnemann, D. and J. Knetsch. 1992. Valuing Public Goods: The Purchase of Moral Satisfaction. Journal of Environmental Economics and Management 22, 57-70.

Kang, Y.-S. and R. Perdue. 1994. Long-Term Impact of a Mega-Event on International Tourism to the Host Country: A Conceptual Model and the Case of the 1988 Seoul Olympics. Journal of International Consumer Marketing 6, 205-225.

McDonald, J. R. and R. A. Moffit. 1980. The Uses of Tobit Analysis. Review of Economics and Statistics 62, 318-321.

Milligan, K., Moretti, E., and P. Oreopoulos. 2004. Does Education Improve Citizenship? Evidence from the United States and the United Kingdom. Journal of Public Economics 88, 1667-1695. 
Nelson, P. 1970. Information and Consumer Behavior. Journal of Political Economy 78, 311-329.

Nunes, P. A. L. D. and E. Schokkaert. 2003. Identifying the Warm Glow Effect in Contingent Valuation. Journal of Environmental Economics and Management 45, 231-245.

Ploeg, R. van der. 2002. In Art We Trust. De Economist 150, 333-362.

Poe, G. L., Clark, J. E., Rondeau, D., and W. D. Schulze. 2002. Provision Point Mechanisms and Field Validity Tests of Contingent Valuation. Environmental and Resource Economics 23, 105-131.

Redding, S. J. and D. M. Sturm. 2008. The Costs of Remoteness: Evidence from German Division and Reunification. American Economic Review 98, 1766-1797.

Reiling, S. D., Boyle, K. J., Phillips, M. L., and M. W. Anderson. 1990. Temporal Reliability of Contingent Values. Land Economics 66, 128-134.

Rondeau, D., Schulze, W. D., and G. L. Poe. 1999. Voluntary Revelation in the Demand for Public Goods Using a Provision Point Mechanism. Journal of Public Economics 72, 455-470.

Schkade, D. and J. Payne. 1994. How People Respond to Contingent Valuation Questions: A Verbal Protocol Analysis of Willingness to Pay for an Environmental Regulation. Journal of Environmental Economics and Management 26, 88-109.

Szymanski, S. 2002. The Economic Impact of the World Cup. World Economics 3, 169177.

Teigland, J. 1999. Mega-Events and Impacts on Tourism: The Predictions and Realities of the Lillehammer Olympics. Impact Assessment and Project Appraisal 17, 305317.

Ungern-Sternberg, T. von and C. C. von Weizsäcker. 1985. The Supply of Quality on a Market for "Experience Goods". Journal of Industrial Economics 33, 531-540.

Whitehead, J. C. 2006. A Practitioner's Primer on Contingent Valuation. in Alberini, A. and J. R. Kahn (eds.). Handbook on Contingent Valuation. Cheltenham, U.K.: Edward Elgar, 92-115. 
Table 1. Censored regression models and sample selectivity

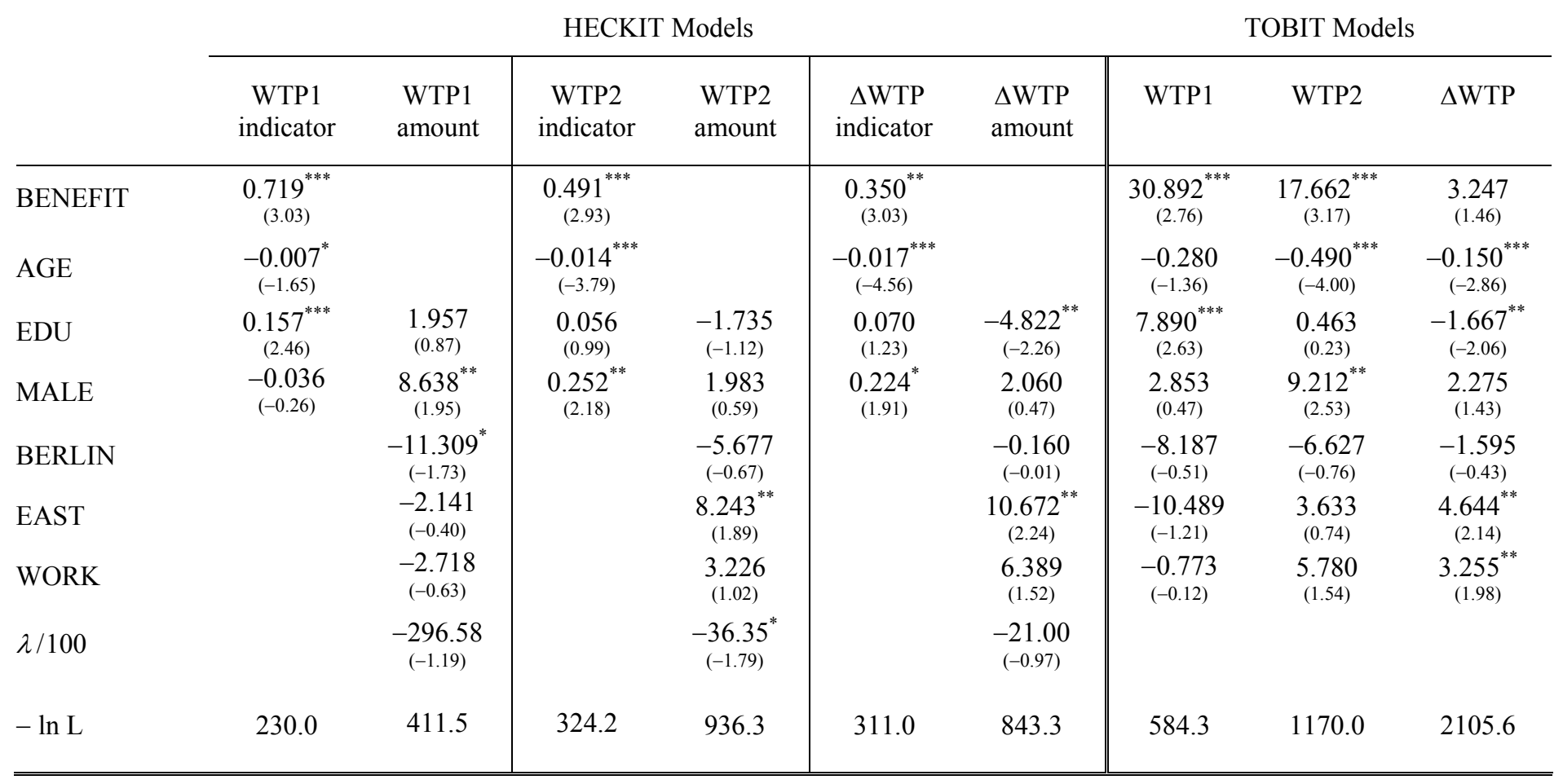

WTP1 - ex-ante WTP, WTP2 - ex-post WTP, $\triangle$ WTP = (WTP2-WTP1), ‘indicator’ refers to 0/1 decision (Heckit Step I: Binary Probit); 'amount' refers to actual amount $\in[0,70]$ or $\in[-70,70]$ (Heckit Step II); *,**,*** denotes significance at 10, 5, 1\% level; all estimates include a constant; values in parentheses give $z$-statistics for the censored models, else they represent corrected $t$-statistics; $\lambda$ denotes the inverse Mill's Ratio. 
Table 2. Summary statistics: dependent variables

\begin{tabular}{lrrr} 
Summary Statistics & WTP1 & $\Delta$ WTP & WTP2 \\
\hline Mean & 4.260 & 5.805 & 10.065 \\
Max & 70 & 70 & 70 \\
Min & 0 & -70 & 0 \\
Range & 70 & 140 & 70 \\
Standard deviation & 12.770 & 17.684 & 17.999 \\
Coefficient of variation & 2.998 & 3.046 & 1.788 \\
Skewness & 3.760 & 0.916 & 1.951 \\
Median & 0 & 0 & 0 \\
Interquartile range & 0 & 7.5 & 7.5 \\
$\mathrm{~N}$ & 500 & 500 & 500 \\
\hline \hline
\end{tabular}

Table 3. Summary statistics: independent variables (excluding dummies)

\begin{tabular}{lrrrrr} 
Summary Statistics & AGE & SCHOOL & EDU & GDRYRS & INC \\
\hline Mean & 42.666 & 10.168 & 2.692 & 2.908 & 4.037 \\
Max & 70 & 19 & 5 & 36 & 9 \\
Min & 15 & 4 & 1 & 0 & 1 \\
Range & 55 & 15 & 4 & 36 & 8 \\
Standard deviation & 15.143 & 3.223 & 1.008 & 7.906 & 2.026 \\
Coefficient of variation & 0.3558 & 0.317 & 0.374 & 2.719 & 0.502 \\
Skewness & 0.015 & 1.291 & 0.739 & 2.799 & 0.458 \\
Median & 42 & 10 & 3 & 0 & 4 \\
Interquartile range & 24 & 1 & 1 & 0 & 3 \\
N & 500 & 500 & 500 & 500 & 400 \\
\hline \hline
\end{tabular}

Note: EDU and INC are categorical variables; EDU ranges from no certificate (category 1), German equivalent of CSE: qualifizierender Hauptschulabschluss (category 2), German equivalent of GCSE: mittlere Reife (category 3), German equivalent of A levels: (Fach-)Abitur (category 4) to university degree (category 5); INC refers to monthly net income; it has been asked for in 9 intervals with a range of 500 Euros each $(0-500,500-1.000,1.000-1.500, \ldots, 3.500-4.000$, more than 4.000). 
Table 4. Marginal effects: WTP1-Tobit (continued on next page)

\begin{tabular}{|c|c|c|c|c|c|c|c|c|c|c|}
\hline M.E.: Probab & censored & $\mathrm{i}$ & ii & iii & iv & $\mathrm{v}$ & vi & vii & viii & ix \\
\hline BENEFIT & $\begin{array}{c}0.140^{* *} \\
(0.02)\end{array}$ & $\begin{array}{c}0.137^{* *} \\
(0.02)\end{array}$ & $\begin{array}{c}0.136^{* *} \\
(0.02)\end{array}$ & $\begin{array}{c}0.135^{* *} \\
(0.02)\end{array}$ & $\begin{array}{c}0.134^{* * *} \\
(0.02)\end{array}$ & $\begin{array}{c}0.137^{* *} \\
(0.02)\end{array}$ & $\begin{array}{c}0.137^{* *} \\
(0.02)\end{array}$ & $\begin{array}{c}0.137^{* *} \\
(0.02)\end{array}$ & $\begin{array}{c}0.157^{* *} \\
(0.02)\end{array}$ & $\begin{array}{c}0.158^{* * *} \\
(0.02)\end{array}$ \\
\hline AGE & & $\begin{array}{c}-0.001 \\
(0.16)\end{array}$ & $\begin{array}{c}-0.001 \\
(0.17)\end{array}$ & $\begin{array}{c}-0.001 \\
(0.17)\end{array}$ & $\begin{array}{c}-0.001 \\
(0.25)\end{array}$ & $\begin{array}{c}-0.001 \\
(0.19)\end{array}$ & $\begin{array}{c}-0.001 \\
(0.30)\end{array}$ & $\begin{array}{c}-0.001 \\
(0.19)\end{array}$ & $\begin{array}{c}-0.002^{*} \\
(0.09)\end{array}$ & $\begin{array}{c}-0.002 \\
(0.11)\end{array}$ \\
\hline MALE & & & $\begin{array}{c}0.021 \\
(0.50)\end{array}$ & $\begin{array}{c}0.019 \\
(0.54)\end{array}$ & $\begin{array}{c}0.019 \\
(0.54)\end{array}$ & $\begin{array}{c}0.011 \\
(0.72)\end{array}$ & $\begin{array}{c}0.012 \\
(0.70)\end{array}$ & $\begin{array}{c}0.011 \\
(0.72)\end{array}$ & $\begin{array}{c}0.018 \\
(0.62)\end{array}$ & $\begin{array}{c}0.014 \\
(0.71)\end{array}$ \\
\hline BERLIN & & & & $\begin{array}{c}-0.074 \\
(0.33)\end{array}$ & $\begin{array}{c}-0.066 \\
(0.41)\end{array}$ & $\begin{array}{c}-0.061 \\
(0.45)\end{array}$ & $\begin{array}{c}-0.064 \\
(0.43)\end{array}$ & $\begin{array}{c}-0.062 \\
(0.44)\end{array}$ & $\begin{array}{c}-0.070 \\
(0.49)\end{array}$ & $\begin{array}{c}-0.067 \\
(0.51)\end{array}$ \\
\hline GDRYRS & & & & & $\begin{array}{c}-0.001 \\
(0.68)\end{array}$ & $\begin{array}{c}-0.001 \\
(0.50)\end{array}$ & $\begin{array}{c}-0.001 \\
(0.46)\end{array}$ & $\begin{array}{c}-0.001 \\
(0.49)\end{array}$ & $\begin{array}{c}-0.001 \\
(0.60)\end{array}$ & $\begin{array}{c}-0.001 \\
(0.43)\end{array}$ \\
\hline SCHOOL & & & & & & $\begin{array}{c}0.012^{* * *} \\
(0.01)\end{array}$ & -- & $\begin{array}{c}0.012^{* * *} \\
(0.01)\end{array}$ & -- & $\begin{array}{c}0.010^{*} \\
(0.07)\end{array}$ \\
\hline EDU & & & & & & & $\begin{array}{c}0.042^{* * *} \\
(0.00)\end{array}$ & - & -- & - \\
\hline WORK & & & & & & & & $\begin{array}{c}0.002 \\
(0.95)\end{array}$ & $\begin{array}{c}-0.020 \\
(0.63)\end{array}$ & $\begin{array}{c}-0.028 \\
(0.49)\end{array}$ \\
\hline INC & & & & & & & & & $\begin{array}{c}0.013 \\
(0.19)\end{array}$ & $\begin{array}{c}0.010 \\
(0.32)\end{array}$ \\
\hline \multicolumn{11}{|c|}{ M.E.: Conditional on being uncensored } \\
\hline BENEFIT & $\begin{array}{c}5.339^{* * *} \\
(0.00)\end{array}$ & $\begin{array}{c}5.192^{* * * *} \\
(0.01)\end{array}$ & $\begin{array}{c}5.142^{* * *} \\
(0.01)\end{array}$ & $\begin{array}{c}5.072^{* * *} \\
(0.01)\end{array}$ & $\begin{array}{c}5.054^{* * * *} \\
(0.01)\end{array}$ & $\begin{array}{c}5.146^{* * *} \\
(0.01)\end{array}$ & $\begin{array}{c}5.136^{* * *} \\
(0.01)\end{array}$ & $\begin{array}{c}5.106^{* * *} \\
(0.01)\end{array}$ & $\begin{array}{c}5.613^{* * *} \\
(0.01)\end{array}$ & $\begin{array}{c}5.689^{* * *} \\
(0.01)\end{array}$ \\
\hline AGE & & $\begin{array}{c}-0.051 \\
(0.16)\end{array}$ & $\begin{array}{c}-0.050 \\
(0.17)\end{array}$ & $\begin{array}{c}-0.051 \\
(0.17)\end{array}$ & $\begin{array}{c}-0.045 \\
(0.25)\end{array}$ & $\begin{array}{c}-0.051 \\
(0.19)\end{array}$ & $\begin{array}{c}-0.040 \\
(0.30)\end{array}$ & $\begin{array}{c}-0.051 \\
(0.19)\end{array}$ & $\begin{array}{c}-0.080^{*} \\
(0.09)\end{array}$ & $\begin{array}{c}-0.075 \\
(0.11)\end{array}$ \\
\hline MALE & & & $\begin{array}{c}0.742 \\
(0.50)\end{array}$ & $\begin{array}{c}0.666 \\
(0.54)\end{array}$ & $\begin{array}{c}0.670 \\
(0.54)\end{array}$ & $\begin{array}{c}0.384 \\
(0.72)\end{array}$ & $\begin{array}{c}0.415 \\
(0.70)\end{array}$ & $\begin{array}{c}0.393 \\
(0.72)\end{array}$ & $\begin{array}{c}0.605 \\
(0.62)\end{array}$ & $\begin{array}{c}0.456 \\
(0.71)\end{array}$ \\
\hline BERLIN & & & & $\begin{array}{c}-2.683 \\
(0.30)\end{array}$ & $\begin{array}{c}-2.376 \\
(0.39)\end{array}$ & $\begin{array}{c}-2.168 \\
(0.42)\end{array}$ & $\begin{array}{c}-2.262 \\
(0.41)\end{array}$ & $\begin{array}{c}-2.198 \\
(0.42)\end{array}$ & $\begin{array}{c}-2.363 \\
(0.47)\end{array}$ & $\begin{array}{c}-2.265 \\
(0.49)\end{array}$ \\
\hline GDRYRS & & & & & $\begin{array}{c}-0.019 \\
(0.68)\end{array}$ & $\begin{array}{c}-0.323 \\
(0.50)\end{array}$ & $\begin{array}{c}-0.035 \\
(0.46)\end{array}$ & $\begin{array}{c}-0.033 \\
(0.49)\end{array}$ & $\begin{array}{c}-0.027 \\
(0.60)\end{array}$ & $\begin{array}{c}-0.041 \\
(0.43)\end{array}$ \\
\hline SCHOOL & & & & & & $\begin{array}{c}0.415^{* * *} \\
(0.01)\end{array}$ & - & $\begin{array}{c}0.411^{* * *} \\
(0.01)\end{array}$ & -- & $\begin{array}{c}0.351^{*} \\
(0.07)\end{array}$ \\
\hline EDU & & & & & & & $\begin{array}{c}1.435^{* * *} \\
(0.00)\end{array}$ & -- & -- & -- \\
\hline WORK & & & & & & & & $\begin{array}{c}0.069 \\
(0.95)\end{array}$ & $\begin{array}{c}-0.646 \\
(0.63)\end{array}$ & $\begin{array}{c}-0.906 \\
(0.49)\end{array}$ \\
\hline INC & & & & & & & & & $\begin{array}{c}0.429 \\
(0.19)\end{array}$ & $\begin{array}{c}0.328 \\
(0.32)\end{array}$ \\
\hline
\end{tabular}


Table 4. Marginal effects: WTP1-Tobit (continued)

M.E.: Unconditional expected value

\begin{tabular}{|c|c|c|c|c|c|c|c|c|c|c|}
\hline BENEFIT & $\begin{array}{c}3.709^{* *} \\
(0.03)\end{array}$ & $\begin{array}{c}3.609^{* *} \\
(0.04)\end{array}$ & $\begin{array}{c}3.580^{* *} \\
(0.04)\end{array}$ & $\begin{array}{c}3.526^{* *} \\
(0.04)\end{array}$ & $\begin{array}{c}3.515^{* *} \\
(0.04)\end{array}$ & $\begin{array}{c}3.504^{* *} \\
(0.03)\end{array}$ & $\begin{array}{c}3.487^{* *} \\
(0.03)\end{array}$ & $\begin{array}{c}3.502^{* *} \\
(0.04)\end{array}$ & $\begin{array}{c}4.147^{* *} \\
(0.04)\end{array}$ & $\begin{array}{c}4.144^{* *} \\
(0.04)\end{array}$ \\
\hline AGE & & $\begin{array}{c}-0.043 \\
(0.16)\end{array}$ & $\begin{array}{c}-0.043 \\
(0.17)\end{array}$ & $\begin{array}{c}-0.043 \\
(0.17)\end{array}$ & $\begin{array}{c}-0.038 \\
(0.25)\end{array}$ & $\begin{array}{c}-0.043 \\
(0.19)\end{array}$ & $\begin{array}{c}-0.034 \\
(0.30)\end{array}$ & $\begin{array}{c}-0.043 \\
(0.19)\end{array}$ & $\begin{array}{c}-0.072^{*} \\
(0.09)\end{array}$ & $\begin{array}{c}-0.068 \\
(0.11)\end{array}$ \\
\hline MALE & & & $\begin{array}{c}0.629 \\
(0.50)\end{array}$ & $\begin{array}{c}0.563 \\
(0.54)\end{array}$ & $\begin{array}{c}0.566 \\
(0.54)\end{array}$ & $\begin{array}{l}0.321 \\
(0.72)\end{array}$ & $\begin{array}{c}0.346 \\
(0.70)\end{array}$ & $\begin{array}{c}0.331 \\
(0.72)\end{array}$ & $\begin{array}{l}0.548 \\
(0.62)\end{array}$ & $\begin{array}{c}0.409 \\
(0.71)\end{array}$ \\
\hline BERLIN & & & & $\begin{array}{c}-1.988 \\
(0.37)\end{array}$ & $\begin{array}{c}-1.789 \\
(0.44)\end{array}$ & $\begin{array}{c}-1.627 \\
(0.47)\end{array}$ & $\begin{array}{c}-1.684 \\
(0.46)\end{array}$ & $\begin{array}{c}-1.659 \\
(0.47)\end{array}$ & $\begin{array}{c}-1.924 \\
(0.52)\end{array}$ & $\begin{array}{c}-1.836 \\
(0.53)\end{array}$ \\
\hline GDRYRS & & & & & $\begin{array}{c}-0.016 \\
(0.68)\end{array}$ & $\begin{array}{c}-0.027 \\
(0.50)\end{array}$ & $\begin{array}{c}-0.029 \\
(0.46)\end{array}$ & $\begin{array}{c}-0.027 \\
(0.49)\end{array}$ & $\begin{array}{c}-0.025 \\
(0.60)\end{array}$ & $\begin{array}{c}-0.037 \\
(0.43)\end{array}$ \\
\hline SCHOOL & & & & & & $\begin{array}{c}0.347^{* * *} \\
(0.01)\end{array}$ & -- & $\begin{array}{c}0.346^{* * *} \\
(0.01)\end{array}$ & - & $\begin{array}{c}0.315^{*} \\
(0.07)\end{array}$ \\
\hline EDU & & & & & & & $\begin{array}{c}1.197^{* * *} \\
(0.00)\end{array}$ & -- & -- & -- \\
\hline WORK & & & & & & & & $\begin{array}{c}0.058 \\
(0.95)\end{array}$ & $\begin{array}{c}-0.585 \\
(0.63)\end{array}$ & $\begin{array}{c}-0.816 \\
(0.49)\end{array}$ \\
\hline INC & & & & & & & & & $\begin{array}{c}0.388 \\
(0.19)\end{array}$ & $\begin{array}{c}0.294 \\
(0.32)\end{array}$ \\
\hline $\mathrm{N}$ & 500 & 500 & 500 & 500 & 500 & 500 & 500 & 496 & 400 & 400 \\
\hline $\ln \mathrm{L}$ & -619.28 & -618.31 & -618.09 & -617.43 & -617.34 & -614.04 & -613.61 & -613.45 & -546.47 & -544.82 \\
\hline
\end{tabular}

Note: p-values given in parentheses; $*$,***** denotes significance at 10, 5, 1\% level; all estimates include a constant; one-sided (left-)censored model Robustness of estimates:

(i) Using the dichotomous EAST instead of GDRYRS, as in Alesina and Fuchs-Schündeln (2007) and Table 1, does not (qualitatively) alter results;

(ii) INC has been used in its categorical representation (Table 3); estimates are robust with regard to other representations of INC;

(iii) Using a two-sided censored model (Table 1) does not (qualitatively) alter results;

(iv) Excluding BENEFIT from regressions does not (qualitatively) alter results;

sensitivity analysis detail (i) to (iv) is available on request from the authors. 
Table 5. Marginal effects: $\Delta$ WTP-Tobit (continued on next page)

\begin{tabular}{|c|c|c|c|c|c|c|c|c|c|c|}
\hline \multicolumn{2}{|c|}{ M.E.: Probability uncensored ${ }^{\dagger}$} & $\mathrm{i}$ & ii & iii & iv & $\mathrm{v}$ & vi & vii & viii & ix \\
\hline BENEFIT & $\begin{array}{c}0.106^{* *} \\
(0.03)\end{array}$ & $\begin{array}{c}0.079^{*} \\
(0.06)\end{array}$ & $\begin{array}{c}0.069^{*} \\
(0.09)\end{array}$ & $\begin{array}{c}0.071^{*} \\
(0.08)\end{array}$ & $\begin{array}{c}0.072^{*} \\
(0.07)\end{array}$ & $\begin{array}{c}0.065^{*} \\
(0.07)\end{array}$ & $\begin{array}{c}0.066^{*} \\
(0.07)\end{array}$ & $\begin{array}{c}0.074^{* *} \\
(0.04)\end{array}$ & $\begin{array}{c}0.119^{* *} \\
(0.05)\end{array}$ & $\begin{array}{c}0.116^{* *} \\
(0.04)\end{array}$ \\
\hline AGE & & $\begin{array}{c}-0.002^{* * *} \\
(0.00)\end{array}$ & $\begin{array}{c}-0.002^{* * *} \\
(0.00)\end{array}$ & $\begin{array}{c}-0.002^{* * * *} \\
(0.00)\end{array}$ & $\begin{array}{c}-0.003^{* * *} \\
(0.00)\end{array}$ & $\begin{array}{c}-0.002^{* * *} \\
(0.00)\end{array}$ & $\begin{array}{c}-0.003^{* * *} \\
(0.00)\end{array}$ & $\begin{array}{c}-0.002^{* * *} \\
(0.00)\end{array}$ & $\begin{array}{c}-0.004^{* * *} \\
(0.01)\end{array}$ & $\begin{array}{c}-0.004^{* * *} \\
(0.01)\end{array}$ \\
\hline MALE & & & $\begin{array}{c}0.041 \\
(0.16)\end{array}$ & $\begin{array}{c}0.042 \\
(0.15)\end{array}$ & $\begin{array}{c}0.039 \\
(0.16)\end{array}$ & $\begin{array}{c}0.041 \\
(0.12)\end{array}$ & $\begin{array}{c}0.040 \\
(0.13)\end{array}$ & $\begin{array}{c}0.037 \\
(0.15)\end{array}$ & $\begin{array}{c}0.071^{*} \\
(0.10)\end{array}$ & $\begin{array}{c}0.070^{*} \\
(0.09)\end{array}$ \\
\hline BERLIN & & & & $\begin{array}{c}0.032 \\
(0.60)\end{array}$ & $\begin{array}{c}-0.005 \\
(0.93)\end{array}$ & $\begin{array}{c}-0.010 \\
(0.85)\end{array}$ & $\begin{array}{c}-0.009 \\
(0.86)\end{array}$ & $\begin{array}{c}-0.014 \\
(0.80)\end{array}$ & $\begin{array}{c}-0.003 \\
(0.97)\end{array}$ & $\begin{array}{c}-0.007 \\
(0.93)\end{array}$ \\
\hline GDRYRS & & & & & $\begin{array}{c}0.002^{*} \\
(0.08)\end{array}$ & $\begin{array}{c}0.002^{* *} \\
(0.05)\end{array}$ & $\begin{array}{c}0.002^{* *} \\
(0.05)\end{array}$ & $\begin{array}{c}0.002^{* *} \\
(0.04)\end{array}$ & $\begin{array}{c}0.002^{*} \\
(0.09)\end{array}$ & $\begin{array}{c}0.003^{*} \\
(0.06)\end{array}$ \\
\hline SCHOOL & & & & & & $\begin{array}{c}-0.007^{* *} \\
(0.05)\end{array}$ & -- & $\begin{array}{c}-0.009^{* *} \\
(0.02)\end{array}$ & -- & $\begin{array}{c}-0.010 \\
(0.13)\end{array}$ \\
\hline EDU & & & & & & & $\begin{array}{c}-0.022^{*} \\
(0.09)\end{array}$ & - & - & - \\
\hline WORK & & & & & & & & $\begin{array}{c}0.053^{* *} \\
(0.04)\end{array}$ & $\begin{array}{c}0.097^{* *} \\
(0.03)\end{array}$ & $\begin{array}{c}0.101^{* *} \\
(0.02)\end{array}$ \\
\hline INC & & & & & & & & & $\begin{array}{c}0.008 \\
(0.49)\end{array}$ & $\begin{array}{c}0.004 \\
(0.69)\end{array}$ \\
\hline \multicolumn{11}{|c|}{ M.E.: Conditional on being uncensored } \\
\hline BENEFIT & $\begin{array}{c}3.433 \\
(0.11)\end{array}$ & $\begin{array}{c}3.026 \\
(0.16)\end{array}$ & $\begin{array}{c}2.806 \\
(0.19)\end{array}$ & $\begin{array}{c}2.895 \\
(0.18)\end{array}$ & $\begin{array}{c}2.963 \\
(0.17)\end{array}$ & $\begin{array}{c}2.932 \\
(0.17)\end{array}$ & $\begin{array}{c}2.938 \\
(0.17)\end{array}$ & $\begin{array}{c}3.254 \\
(0.13)\end{array}$ & $\begin{array}{c}3.537 \\
(0.15)\end{array}$ & $\begin{array}{c}3.595 \\
(0.14)\end{array}$ \\
\hline AGE & & $\begin{array}{c}-0.139^{* * *} \\
(0.00)\end{array}$ & $\begin{array}{c}-0.139^{* * *} \\
(0.00)\end{array}$ & $\begin{array}{c}-0.140^{* * *} \\
(0.00)\end{array}$ & $\begin{array}{c}-0.175^{* * *} \\
(0.00)\end{array}$ & $\begin{array}{c}-0.167^{* * *} \\
(0.00)\end{array}$ & $\begin{array}{c}-0.179^{* * *} \\
(0.00)\end{array}$ & $\begin{array}{c}-0.176^{* * *} \\
(0.00)\end{array}$ & $\begin{array}{c}-0.171^{* * *} \\
(0.01)\end{array}$ & $\begin{array}{c}-0.176^{* * *} \\
(0.01)\end{array}$ \\
\hline MALE & & & $\begin{array}{c}2.158 \\
(0.16)\end{array}$ & $\begin{array}{c}2.201 \\
(0.16)\end{array}$ & $\begin{array}{c}2.169 \\
(0.16)\end{array}$ & $\begin{array}{c}2.391 \\
(0.12)\end{array}$ & $\begin{array}{c}2.328 \\
(0.13)\end{array}$ & $\begin{array}{c}2.238 \\
(0.15)\end{array}$ & $\begin{array}{c}2.855 \\
(0.11)\end{array}$ & $\begin{array}{c}2.959^{*} \\
(0.09)\end{array}$ \\
\hline BERLIN & & & & $\begin{array}{c}2.084 \\
(0.51)\end{array}$ & $\begin{array}{c}-0.290 \\
(0.93)\end{array}$ & $\begin{array}{c}-0.585 \\
(0.86)\end{array}$ & $\begin{array}{c}-0.542 \\
(0.87)\end{array}$ & $\begin{array}{c}-0.779 \\
(0.82)\end{array}$ & $\begin{array}{c}-0.147 \\
(0.97)\end{array}$ & $\begin{array}{c}-0.305 \\
(0.94)\end{array}$ \\
\hline GDRYRS & & & & & $\begin{array}{c}0.113^{*} \\
(0.08)\end{array}$ & $\begin{array}{c}0.124^{* *} \\
(0.05)\end{array}$ & $\begin{array}{c}0.126^{* *} \\
(0.05)\end{array}$ & $\begin{array}{c}0.133^{* *} \\
(0.04)\end{array}$ & $\begin{array}{c}0.120^{*} \\
(0.09)\end{array}$ & $\begin{array}{c}0.135^{*} \\
(0.06)\end{array}$ \\
\hline SCHOOL & & & & & & $\begin{array}{c}-0.464^{* *} \\
(0.05)\end{array}$ & -- & $\begin{array}{c}-0.566^{* *} \\
(0.02)\end{array}$ & -- & $\begin{array}{c}-0.441 \\
(0.13)\end{array}$ \\
\hline EDU & & & & & & & $\begin{array}{c}-1.304^{*} \\
(0.09)\end{array}$ & - & -- & -- \\
\hline WORK & & & & & & & & $\begin{array}{c}3.113^{* *} \\
(0.05)\end{array}$ & $\begin{array}{c}3.797^{* *} \\
(0.04)\end{array}$ & $\begin{array}{c}4.094^{* *} \\
(0.03)\end{array}$ \\
\hline INC & & & & & & & & & $\begin{array}{c}-0.330 \\
(0.49)\end{array}$ & $\begin{array}{c}-0.197 \\
(0.69)\end{array}$ \\
\hline
\end{tabular}


Table 5. Marginal effects: $\Delta$ WTP-Tobit (continued)

M.E.: Unconditional expected value

\begin{tabular}{|c|c|c|c|c|c|c|c|c|c|c|}
\hline BENEFIT & $\begin{array}{c}3.433 \\
(0.11)\end{array}$ & $\begin{array}{c}3.027 \\
(0.16)\end{array}$ & $\begin{array}{c}2.807 \\
(0.19)\end{array}$ & $\begin{array}{c}2.896 \\
(0.18)\end{array}$ & $\begin{array}{c}2.964 \\
(0.17)\end{array}$ & $\begin{array}{c}2.933 \\
(0.17)\end{array}$ & $\begin{array}{c}2.938 \\
(0.17)\end{array}$ & $\begin{array}{c}3.255 \\
(0.04)\end{array}$ & $\begin{array}{c}3.538 \\
(0.15)\end{array}$ & $\begin{array}{c}3.596 \\
(0.14)\end{array}$ \\
\hline AGE & & $\begin{array}{c}-0.139^{* * *} \\
(0.00)\end{array}$ & $\begin{array}{c}-0.139^{* * *} \\
(0.00)\end{array}$ & $\begin{array}{c}-0.140^{* * *} \\
(0.00)\end{array}$ & $\begin{array}{c}-0.175^{* * *} \\
(0.00)\end{array}$ & $\begin{array}{c}-0.167^{* * *} \\
(0.00)\end{array}$ & $\begin{array}{c}-0.179^{* * *} \\
(0.00)\end{array}$ & $\begin{array}{c}-0.176^{* * *} \\
(0.00)\end{array}$ & $\begin{array}{c}-0.171^{* * *} \\
(0.01)\end{array}$ & $\begin{array}{c}-0.176^{* * *} \\
(0.01)\end{array}$ \\
\hline MALE & & & $\begin{array}{c}2.158 \\
(0.16)\end{array}$ & $\begin{array}{c}2.201 \\
(0.16)\end{array}$ & $\begin{array}{c}2.169 \\
(0.16)\end{array}$ & $\begin{array}{c}2.392 \\
(0.12)\end{array}$ & $\begin{array}{c}2.328 \\
(0.13)\end{array}$ & $\begin{array}{c}2.238 \\
(0.15)\end{array}$ & $\begin{array}{c}2.856 \\
(0.11)\end{array}$ & $\begin{array}{c}2.960^{*} \\
(0.09)\end{array}$ \\
\hline BERLIN & & & & $\begin{array}{c}2.085 \\
(0.51)\end{array}$ & $\begin{array}{c}-0.290 \\
(0.93)\end{array}$ & $\begin{array}{c}-0.585 \\
(0.86)\end{array}$ & $\begin{array}{c}-0.543 \\
(0.87)\end{array}$ & $\begin{array}{c}-0.779 \\
(0.82)\end{array}$ & $\begin{array}{c}-0.147 \\
(0.97)\end{array}$ & $\begin{array}{c}-0.305 \\
(0.94)\end{array}$ \\
\hline GDRYRS & & & & & $\begin{array}{c}0.113^{*} \\
(0.08)\end{array}$ & $\begin{array}{c}0.124^{* *} \\
(0.05)\end{array}$ & $\begin{array}{c}0.126^{* *} \\
(0.05)\end{array}$ & $\begin{array}{c}0.133^{* *} \\
(0.04)\end{array}$ & $\begin{array}{c}0.120^{*} \\
(0.09)\end{array}$ & $\begin{array}{c}0.135^{*} \\
(0.06)\end{array}$ \\
\hline SCHOOL & & & & & & $\begin{array}{c}-0.464^{* *} \\
(0.05)\end{array}$ & -- & $\begin{array}{c}-0.566^{* *} \\
(0.02)\end{array}$ & -- & $\begin{array}{c}-0.441 \\
(0.13)\end{array}$ \\
\hline EDU & & & & & & & $\begin{array}{c}-1.304^{*} \\
(0.09)\end{array}$ & - & -- & -- \\
\hline WORK & & & & & & & & $\begin{array}{c}3.113^{* *} \\
(0.05)\end{array}$ & $\begin{array}{c}3.797^{* *} \\
(0.04)\end{array}$ & $\begin{array}{l}4.095^{* *} \\
(0.03)\end{array}$ \\
\hline INC & & & & & & & & & $\begin{array}{c}-0.330 \\
(0.49)\end{array}$ & $\begin{array}{c}-0.197 \\
(0.69)\end{array}$ \\
\hline $\mathrm{N}$ & 500 & 500 & 500 & 500 & 500 & 500 & 500 & 496 & 400 & 400 \\
\hline $\ln \mathrm{L}$ & -2142.68 & -2139.08 & -2138.13 & -2137.92 & -2136.39 & -2134.60 & -2134.99 & -2117.40 & -1715.02 & -1713.89 \\
\hline
\end{tabular}

Note: p-values given in parentheses; $*$,***** denotes significance at 10, 5, 1\% level; all estimates include a constant; one-sided (left-)censored model Robustness of estimates:

(i) Using the dichotomous EAST instead of GDRYRS, as in Alesina and Fuchs-Schündeln (2007) and Table 1, does not (qualitatively) alter results;

(ii) INC has been used in its categorical representation (Table 3); estimates are robust with regard to other representations of INC;

(iii) Using a two-sided censored model (Table 1) does not (qualitatively) alter results;

(iv) Excluding BENEFIT from regressions does not (qualitatively) alter results;

sensitivity analysis detail (i) to (iv) is available on request from the authors. 


\section{Appendix}

List of Abbreviations and Variables

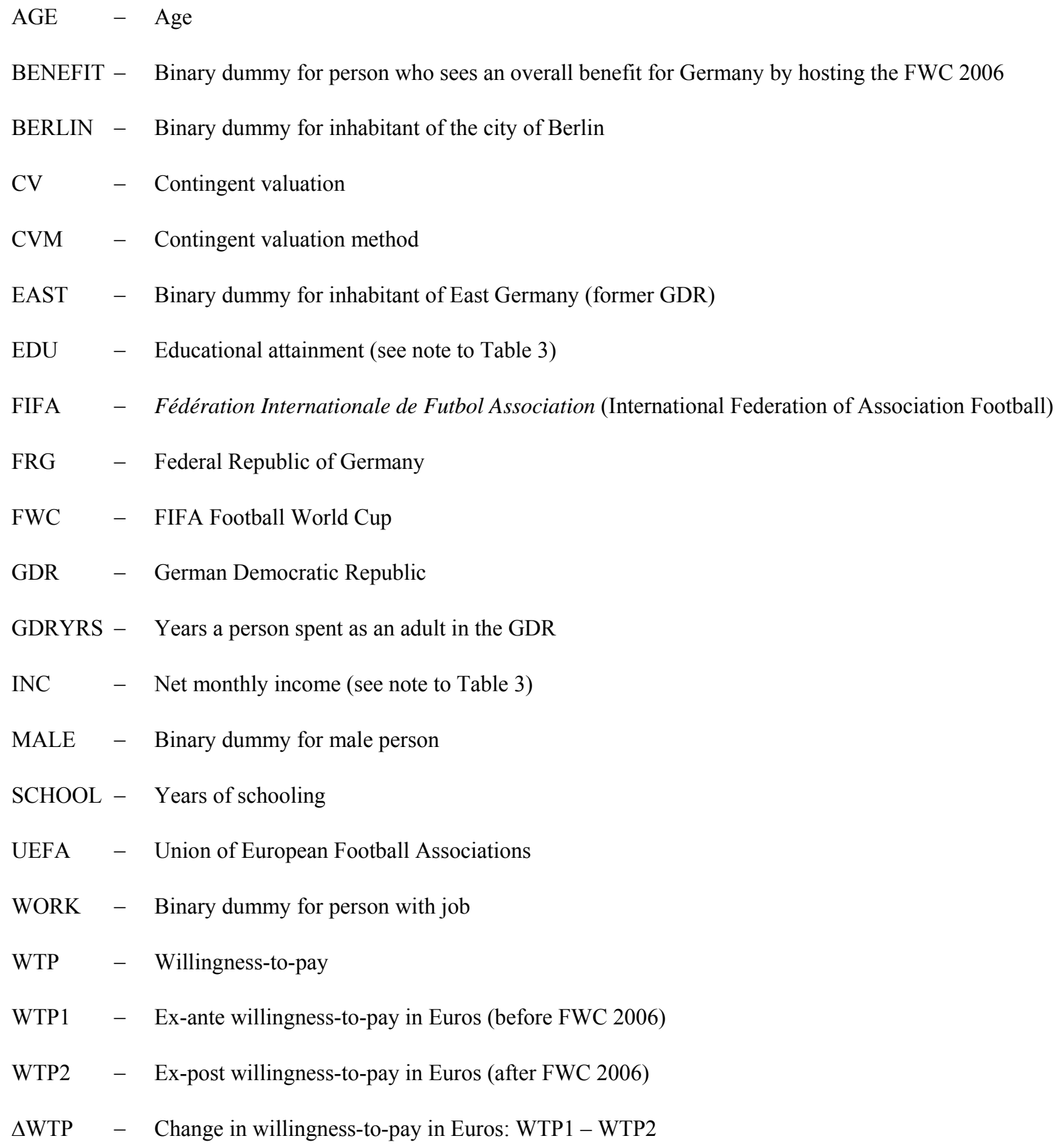




\section{CESifo Working Paper Series}

for full list see www.cesifo-group.org/wp

(address: Poschingerstr. 5, 81679 Munich, Germany, office@cesifo.de)

2521 Geir B. Asheim and Tapan Mitra, Sustainability and Discounted Utilitarianism in Models of Economic Growth, January 2009

2522 Etienne Farvaque and Gaël Lagadec, Electoral Control when Policies are for Sale, January 2009

2523 Nicholas Barr and Peter Diamond, Reforming Pensions, January 2009

2524 Eric A. Hanushek and Ludger Woessmann, Do Better Schools Lead to More Growth? Cognitive Skills, Economic Outcomes, and Causation, January 2009

2525 Richard Arnott and Eren Inci, The Stability of Downtown Parking and Traffic Congestion, January 2009

2526 John Whalley, Jun Yu and Shunming Zhang, Trade Retaliation in a Monetary-Trade Model, January 2009

2527 Mathias Hoffmann and Thomas Nitschka, Securitization of Mortgage Debt, Asset Prices and International Risk Sharing, January 2009

2528 Steven Brakman and Harry Garretsen, Trade and Geography: Paul Krugman and the 2008 Nobel Prize in Economics, January 2009

2529 Bas Jacobs, Dirk Schindler and Hongyan Yang, Optimal Taxation of Risky Human Capital, January 2009

2530 Annette Alstadsæter and Erik Fjærli, Neutral Taxation of Shareholder Income? Corporate Responses to an Announced Dividend Tax, January 2009

2531 Bruno S. Frey and Susanne Neckermann, Academics Appreciate Awards - A New Aspect of Incentives in Research, January 2009

2532 Nannette Lindenberg and Frank Westermann, Common Trends and Common Cycles among Interest Rates of the G7-Countries, January 2009

2533 Erkki Koskela and Jan König, The Role of Profit Sharing in a Dual Labour Market with Flexible Outsourcing, January 2009

2534 Tomasz Michalak, Jacob Engwerda and Joseph Plasmans, Strategic Interactions between Fiscal and Monetary Authorities in a Multi-Country New-Keynesian Model of a Monetary Union, January 2009

2535 Michael Overesch and Johannes Rincke, What Drives Corporate Tax Rates Down? A Reassessment of Globalization, Tax Competition, and Dynamic Adjustment to Shocks, February 2009 
2536 Xenia Matschke and Anja Schöttner, Antidumping as Strategic Trade Policy Under Asymmetric Information, February 2009

2537 John Whalley, Weimin Zhou and Xiaopeng An, Chinese Experience with Global 3G Standard-Setting, February 2009

2538 Claus Thustrup Kreiner and Nicolaj Verdelin, Optimal Provision of Public Goods: A Synthesis, February 2009

2539 Jerome L. Stein, Application of Stochastic Optimal Control to Financial Market Debt Crises, February 2009

2540 Lars P. Feld and Jost H. Heckemeyer, FDI and Taxation: A Meta-Study, February 2009

2541 Philipp C. Bauer and Regina T. Riphahn, Age at School Entry and Intergenerational Educational Mobility, February 2009

2542 Thomas Eichner and Rüdiger Pethig, Carbon Leakage, the Green Paradox and Perfect Future Markets, February 2009

2543 M. Hashem Pesaran, Andreas Pick and Allan Timmermann, Variable Selection and Inference for Multi-period Forecasting Problems, February 2009

2544 Mathias Hoffmann and Iryna Shcherbakova, Consumption Risk Sharing over the Business Cycle: the Role of Small Firms' Access to Credit Markets, February 2009

2545 John Beirne, Guglielmo Maria Caporale, Marianne Schulze-Ghattas and Nicola Spagnolo, Volatility Spillovers and Contagion from Mature to Emerging Stock Markets, February 2009

2546 Ali Bayar and Bram Smeets, Economic and Political Determinants of Budget Deficits in the European Union: A Dynamic Random Coefficient Approach, February 2009

2547 Jan K. Brueckner and Anming Zhang, Airline Emission Charges: Effects on Airfares, Service Quality, and Aircraft Design, February 2009

2548 Dolores Messer and Stefan C. Wolter, Money Matters - Evidence from a Large-Scale Randomized Field Experiment with Vouchers for Adult Training, February 2009

2549 Johannes Rincke and Christian Traxler, Deterrence through Word of Mouth, February 2009

2550 Gabriella Legrenzi, Asymmetric and Non-Linear Adjustments in Local Fiscal Policy, February 2009

2551 Bruno S. Frey, David A. Savage and Benno Torgler, Surviving the Titanic Disaster: Economic, Natural and Social Determinants, February 2009

2552 Per Engström, Patrik Hesselius and Bertil Holmlund, Vacancy Referrals, Job Search, and the Duration of Unemployment: A Randomized Experiment, February 2009 
2553 Giorgio Bellettini, Carlotta Berti Ceroni and Giovanni Prarolo, Political Persistence, Connections and Economic Growth, February 2009

2554 Steinar Holden and Fredrik Wulfsberg, Wage Rigidity, Institutions, and Inflation, February 2009

2555 Alexander Haupt and Tim Krieger, The Role of Mobility in Tax and Subsidy Competition, February 2009

2556 Harald Badinger and Peter Egger, Estimation of Higher-Order Spatial Autoregressive Panel Data Error Component Models, February 2009

2557 Christian Keuschnigg, Corporate Taxation and the Welfare State, February 2009

2558 Marcel Gérard, Hubert Jayet and Sonia Paty, Tax Interactions among Belgian Municipalities: Does Language Matter?, February 2009

2559 António Afonso and Christophe Rault, Budgetary and External Imbalances Relationship: A Panel Data Diagnostic, February 2009

2560 Stefan Krasa and Mattias Polborn, Political Competition between Differentiated Candidates, February 2009

2561 Carsten Hefeker, Taxation, Corruption and the Exchange Rate Regime, February 2009

2562 Jiahua Che and Gerald Willmann, The Economics of a Multilateral Investment Agreement, February 2009

2563 Scott Alan Carson, Demographic, Residential, and Socioeconomic Effects on the Distribution of $19^{\text {th }}$ Century US White Statures, February 2009

2564 Philipp Harms, Oliver Lorz and Dieter Urban, Offshoring along the Production Chain, February 2009

2565 Patricia Apps, Ngo Van Long and Ray Rees, Optimal Piecewise Linear Income Taxation, February 2009

2566 John Whalley and Shunming Zhang, On the Arbitrariness of Consumption, February 2009

2567 Marie-Louise Leroux, Endogenous Differential Mortality, Non-Contractible Effort and Non Linear Taxation, March 2009

2568 Joanna Bęza-Bojanowska and Ronald MacDonald, The Behavioural Zloty/Euro Equilibrium Exchange Rate, March 2009

2569 Bart Cockx and Matteo Picchio, Are Short-Lived Jobs Stepping Stones to Long-Lasting Jobs?, March 2009 
2570 David Card, Jochen Kluve and Andrea Weber, Active Labor Market Policy Evaluations: A Meta-analysis, March 2009

2571 Frederick van der Ploeg and Anthony J. Venables, Harnessing Windfall Revenues: Optimal Policies for Resource-Rich Developing Economies, March 2009

2572 Ondřej Schneider, Reforming Pensions in Europe: Economic Fundamentals and Political Factors, March 2009

2573 Jo Thori Lind, Karl Ove Moene and Fredrik Willumsen, Opium for the Masses? Conflict-Induced Narcotics Production in Afghanistan, March 2009

2574 Silvia Marchesi, Laura Sabani and Axel Dreher, Agency and Communication in IMF Conditional Lending: Theory and Empirical Evidence, March 2009

2575 Carlo Altavilla and Matteo Ciccarelli, The Effects of Monetary Policy on Unemployment Dynamics under Model Uncertainty - Evidence from the US and the Euro Area, March 2009

2576 Falko Fecht, Kjell G. Nyborg and Jörg Rocholl, The Price of Liquidity: Bank Characteristics and Market Conditions, March 2009

2577 Giorgio Bellettini and Filippo Taddei, Real Estate Prices and the Importance of Bequest Taxation, March 2009

2578 Annette Bergemann and Regina T. Riphahn, Female Labor Supply and Parental Leave Benefits - The Causal Effect of Paying Higher Transfers for a Shorter Period of Time, March 2009

2579 Thomas Eichner and Rüdiger Pethig, EU-Type Carbon Emissions Trade and the Distributional Impact of Overlapping Emissions Taxes, March 2009

2580 Antonios Antypas, Guglielmo Maria Caporale, Nikolaos Kourogenis and Nikitas Pittis, Selectivity, Market Timing and the Morningstar Star-Rating System, March 2009

2581 António Afonso and Christophe Rault, Bootstrap Panel Granger-Causality between Government Budget and External Deficits for the EU, March 2009

2582 Bernd Süssmuth, Malte Heyne and Wolfgang Maennig, Induced Civic Pride and Integration, March 2009 